\title{
SATISFACTION OF SMALL AND MEDIUM-SIZED COMPANIES WITH THE POLICY OF BANKS
}

\author{
Daiva JUREVIČIENĖ \\ Mykolas Romeris University, Faculty of Economics and Finance Management \\ Ateities str. 20, LT-80303, Vilnius, Lithuania \\ E-mail: daiva.jureviciene@mruni.eu \\ Viktorija SKVARCIANY \\ Mykolas Romeris University, Faculty of Economics and Finance Management \\ Ateities str. 20, LT-80303, Vilnius, Lithuania \\ E-mail: viktorija.skvarciany@gmail.com \\ doi:10.13165/IE-13-7-4-07
}

\begin{abstract}
Satisfaction with the policy of commercial banks concerning SMEs is one of the most important factors affecting the success of commercial banking activities. This paper analyses the scientific approaches to importance of SME satisfaction with the commercial banks. The analysis of scientific publications revealed that one of the most important factors affecting the satisfaction of small and medium-sized enterprises with banks is the policy concerning SMEs. Comparisons of the results of two studies, analysing satisfaction of small and medium-sized enterprises with the policy of commercial banks concerning SMEs, are presented in this article. One study was conducted in Canada in 2002, another one - in Lithuania in 2011. These studies identified and investigated the factors influencing satisfaction of small and medium-sized enterprises with the policy of commercial banks concerning SMEs, i.e., granting of loans corresponding business needs, offering appropriate financial services to business, creating favourable loan conditions, flexible response to changing business needs, business support by a bank during successful company activities period, business support by a bank in the critical moments of company activities, making timely financing decisions. It was found that all relationships between the factors and the satisfaction with the policy of commercial bank are linear and the correlation coefficients are quite high, indicating that the relationship between the factors is strong enough. However, these studies did not reveal statistical significance of the elements and their possible impact on the satisfaction with commercial banks policy. The current study includes all previously investigated factors and was conducted using the questionnaire method. The respondents were employees of Lithuanian small and medium-sized companies. Statistical analysis shows that only granting of loans corresponding business needs, offering appropriate financial services to business, creating favourable loan conditions, flexible response to changing business needs are statistically significant elements for satisfaction of small and medium-sized enterprises with the policy of commercial banks concerning SMEs. In addition, it was found that there is no multi-colinearity, there are no
\end{abstract}


outliers among investigated factors. The regression equation of satisfaction of small and medium-sized enterprises with the policy of commercial banks concerning SMEs indicating the weight of each statistically significant factor to the overall satisfaction with the commercial bank policy was created. In other words, the equation shows how satisfaction with the policy of commercial bank varies changing one of the most important factors and helps predicting changes in satisfaction.

JEL classification: G02, G21.

Keywords: bank policy, satisfaction, commercial banks, small and medium-sized enterprises (SME), regression analysis.

Reikšminiai žodžiai: banko politika, pasitenkinimas, komerciniai bankai, smulkaus ir vidutinio verslo įmonès, regresinè analizè.

\section{Introduction}

Client satisfaction has become an increasingly important aspect of evaluation of professional services (Bennett, 2007). Customers perceive not much difference in the banking products offered by private banks dealing with services, as competitors quickly match any new offering (Ravichandran et al., 2010). Therefore, winning customer satisfaction through superior service has become a particular strive to pursue (Al-Eisa, Alhemond, 2009), as customer satisfaction is considered to be a vital element in any strategy for service-led business performance improvement (Jones, 1996). What is more, Gill et al. (2006) assume that unsatisfied client will look for other service providers and satisfied clients will continue to use service by providers whose services exceed expectations. Furthermore, customer satisfaction is one of the key elements influencing customers' loyalty (Vegholm, Silver, 2008; Kantsperger, Kunz, 2010; Yap et al., 2012), benevolence (Kantsperger, Kunz, 2010), credibility (Kantsperger, Kunz, 2010) and trust (Žvirelienè, Bičiūnienè, 2008; Yap et al., 2012).

Banks normally divide their customers into individual and corporate (business) ones. The most important in the last group is small and medium-sized business, as it is considered to be one of the most promising sectors of Lithuanian economy (Adamoniené, Trifonova, 2007). According to Vegholm (2011), the banks relationships with small and medium-sized companies' customers influence banks' image. Narteh (2013) claims that banks staff should display high professionalism and strive for the satisfaction of their SME customers in order to be considered in the choice set. Madill et al. (2002) say that the more satisfied SME client, the less likely the SME will switch banks. Moreover, according to the research made by Madill et al. (2002), there are three main elements having a major impact on overall SME satisfaction with the financial institution: 1) performance of an account manager in relationship management; 2) satisfaction with corporate relationship policies and procedures; 3 ) performance of branch staff in relationship management. Furthermore, Madill's et al. (2002) research shows that satisfaction with corporate policy and procedures have a larger impact on overall customer satisfaction than do the others - the account manager or branch staff in managing the relationship. Consequently, satisfaction of Lithuanian small and medium-sized enter- 
prises with the policy of commercial banks concerning SMEs is examined in this paper. Hence, the object of the research is assessing satisfaction of small and medium-sized enterprises with the policy of commercial banks concerning SMEs. The aim of the research is to create a model measuring satisfaction of small and medium-sized enterprises with the policy of commercial banks concerning SMEs. The following objectives are settled: to analyse the determinants influencing SME in selection of banks; to analyse statistical data of satisfaction of small and medium-sized enterprises with the policy of commercial banks concerning SMEs; to carry out a correlation analysis of the data to determine the strength and direction of relationship; to create a model to measure satisfaction of small and medium-sized enterprises with the policy of commercial banks concerning SMEs.

\section{Factors Influencing Satisfaction of Small and Medium-sized Enterprises with the Policy of Commercial Banks}

The policy of commercial banks concerning SMEs can be described as bank activities directed to support business of small and medium-sized enterprises. For this reason, SME select a bank that can meet their needs. There are many scientists analysing satisfaction of small and medium-sized enterprises with bank activities focused on SME commerce support and determinants having impact on it. According to Kaura (2013), the survival of banks depends on customer satisfaction. Narteh (2013) highlights the following elements influencing small and medium-sized enterprises and banks relationship: price competitiveness, credit availability, perceived service quality, staff attributes and bank attributes. According to Lundahl et al. (2009), SME evaluate their banking relationship based on the effectiveness and quality of banks' service outcomes and on the care and manner in which bankers deliver services. Zineldin (1996) suggests that the progress of the relationship between the bank and its corporate client depends on various factors: industry trust, mutual interest dependence, the state of conflict and co-operation and overall closeness or distance of the relationship as well as on the partners' mutual expectations. Zhu and Chen (2012) argue that fairness is an element that is positively related to customer satisfaction.

Although, there are many different factors influencing satisfaction of small and medium-sized enterprises with the policy of commercial banks concerning SMEs, the following elements have been selected for the present research (Madill et al., 2002; Mačerinskienè et al., 2008; Mačerinskienè, Skvarciany, 2012):

$>$ granting of loans corresponding business needs;

$>$ offering appropriate financial services to business;

$>$ creating favourable loan conditions;

$>$ flexible response to changing business needs;

$>$ business support by a bank during a successful company's activities period;

$>$ business support by a bank in the critical moments of company's activities;

$>$ making timely financing decisions.

The elements mentioned above were investigated in Canada in 2002 by Madill et al. (2002) and in Lithuania by Mačerinskiené, Skvarciany (2012) in 2012. 
The correlation analysis was made to measure the relationship between the factors investigated. Actually, Madill et al. (2002) ascertained the relationship between financial institution policies and overall satisfaction with financial institution (see Table 1).

Table 1. Corporate policies, procedures and satisfaction

\begin{tabular}{|l|c|}
\hline \multicolumn{1}{|c|}{ Corporate policies and procedures } & $\begin{array}{c}\text { Overall satisfaction with } \\
\text { financial institution } \\
\text { (Pearson } \boldsymbol{r} \text { ) }\end{array}$ \\
\hline Provides credit and sufficient amounts to meet needs of SME & 0,704 \\
\hline Is flexible in structuring loans & 0,747 \\
\hline Provides convenient business banking & 0,584 \\
\hline Is flexible in meeting changing operational needs of SME's businesses & 0,773 \\
\hline Supports SME in good and difficult times & 0,753 \\
\hline Makes timely decisions regarding financing & 0,691 \\
\hline
\end{tabular}

Source: Madill et al. (2002)

The correlations indicated in Table 1 are quite strong, showing that satisfaction with corporate policies and procedures has an impact on overall customers' satisfaction with financial institution.

Mačerinskienè and Skvarciany (2012) identified the relationship between factors influencing the policy of commercial banks concerning SMEs and overall satisfaction of small and medium-sized enterprises with the policy of commercial banks (see Table 2).

Table 2. Correlation coefficients of the factors influencing satisfaction of small and medium-sized enterprises with the policy of commercial banks concerning SMEs

\begin{tabular}{|l|c|}
\hline \multicolumn{1}{|c|}{ Bank policy towards SME } & $\begin{array}{c}\text { SME overall satisfaction } \\
\text { with bank policy } \\
\text { towards small and } \\
\text { medium-sized } \\
\text { businesses } \\
\text { (Pearson } \boldsymbol{r} \text { ) }\end{array}$ \\
\hline Granting of loans corresponding business needs & \begin{tabular}{c}
0,927 \\
\hline Offering appropriate financial services to business
\end{tabular} \\
\hline Creating favourable loan conditions & 0,845 \\
\hline Flexible response to changing business needs & 0,919 \\
\hline $\begin{array}{l}\text { Business support by a bank during a successful company's } \\
\text { activities period }\end{array}$ & 0,918 \\
\hline $\begin{array}{l}\text { Business support by a bank in the critical moments } \\
\text { of company activities }\end{array}$ & 0,882 \\
\hline Making timely financing decisions & 0,946 \\
\hline
\end{tabular}

Source: Mačerinskienè and Skvarciany (2012) 
In fact, all correlations indicated in Table 2 are strong and mean a major impact on overall customer satisfaction of small and medium-sized enterprises with the policy of commercial banks concerning SMEs by the factors investigated. Hence, it is important to improve overall satisfaction of small and medium-sized enterprises with the policy of commercial banks concerning SMEs for the successful activities of banks, retaining customers and attracting new clients. It is worth to construct a model measuring overall satisfaction with the policy of commercial banks concerning SMEs.

\section{Empirical Findings}

For identification of the key factors determining satisfaction of small and medium-sized enterprises with the policy of commercial banks concerning SMEs, the same seven variables were investigated: granting of loans corresponding business needs, offering appropriate financial services to business, creating favourable loan conditions, flexible response to changing business needs, business support by a bank during a successful company's activities period, business support by a bank in the critical moments of company's activities and making timely financing decisions. The method of questionnaire was used in order to gain insight of businessmen opinion on the above mentioned questions. Data was collected in Lithuania using electronic survey system. In order to ensure the representativeness of the results, $400^{1}$ companies had to be interviewed. In fact, 405 of the distributed questionnaires were returned. All of the data was included for the analysis. After the regression analysis, statistically significant variables were identified ${ }^{2}$ (see Table 3 ).

1 The number of respondents was calculated using the formula:

where:

$$
n=\frac{1}{\Delta^{2}+\frac{1}{N}},
$$

$n$ - sample size,

$N$ - number of employees of small and medium-sized companies in Lithuania,

$\Delta$ - margin of error $(\Delta=0,05)$.

Applying the formula:

$$
n=\frac{1}{0,05^{2}+\frac{1}{636000}} \approx 400 .
$$

According to statistics (2013), the number of employees of small and medium-sized companies in Lithuania was 636000.

2 The variable is statistically significant when Sig. $<0.05$. 
Table 3. Statistical significance of the independent variables

\begin{tabular}{|l|c|}
\hline \multicolumn{1}{|c|}{ Variables } & Sig. \\
\hline Constant & 0,000 \\
\hline Granting of loans corresponding business needs & 0,008 \\
\hline Offering appropriate financial services to business & 0,001 \\
\hline Creating favourable loan conditions & 0,036 \\
\hline Flexible response to changing business needs & 0,000 \\
\hline Business support by a bank during a successful company's activities period & 0,993 \\
\hline Business support by a bank in the critical moments of company's activities & 0,264 \\
\hline Making timely financing decisions & 0,267 \\
\hline
\end{tabular}

Source: designed by the authors

The analysis shows that some elements have no impact on satisfaction with the policy of commercial banks concerning SMEs, i.e., business support by a bank during a successful company's activities period, business support by a bank in the critical moments of company's activities, making timely financing decisions (see Table 3). Consequently, these elements were withdrawn from further analysis and the model of satisfaction with bank policies was created containing only statistically significant variables (see Figure 1).

Figure 1. The model of formation of satisfaction of small and medium-sized enterprises with the policy of commercial banks concerning SMEs

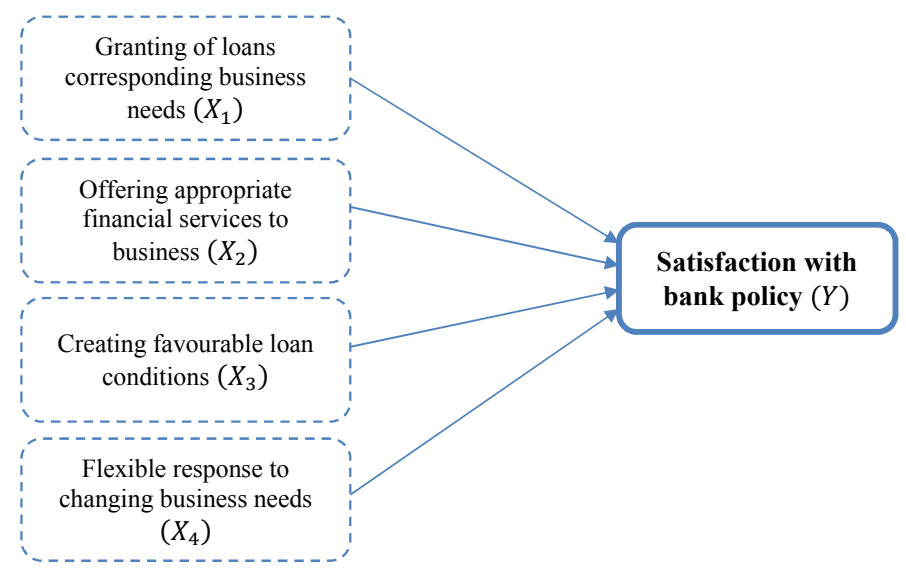

Source: designed by the authors where:

The test model can be written as: $Y=f\left(X_{1}, X_{2}, X_{3}, X_{4}\right)$,

$Y$ - satisfaction of small and medium-sized enterprises with the policy of commercial banks concerning SMEs; 
$X_{1}$ - granting of loans corresponding business needs;

$X_{2}$ - offering appropriate financial services to business;

$X_{3}$ - creating favourable loan conditions;

$X_{4}$ - flexible response to changing business needs.

First of all, it is necessary to set the strength of the relationship between satisfaction with bank policy and factors influencing it. Correlations between variables are presented in Table 4. Actually, all the correlations are quite strong and it is evident that all four statistically significant variables are related to overall satisfaction of small and mediumsized enterprises with the policy of commercial banks concerning SMEs. Really, this means that all the variables are directly proportional to satisfaction with banks' policies.

Table 4. Correlation coefficients of the factors influencing satisfaction of small and medium-sized enterprises with the policy of commercial banks concerning SMEs

\begin{tabular}{|l|c|}
\hline \multicolumn{1}{|c|}{ Bank's policy towards SME } & $\begin{array}{c}\text { Overall satisfaction with the } \\
\text { policy of commercial banks } \\
\text { (Pearson } \boldsymbol{r} \text { ) }\end{array}$ \\
\hline Granting of loans corresponding business needs & 0,627 \\
\hline Offering appropriate financial services to business & 0,529 \\
\hline Creating favourable loan conditions & 0,649 \\
\hline Flexible response to changing business needs & 0,675 \\
\hline
\end{tabular}

Source: designed by the authors

In addition, the regression analysis was carried out to construct an equation measuring an overall satisfaction with the policy of commercial banks concerning SMEs. The results of the analysis are indicated in Table 5 . The four variables $\left(X_{i}, i=1, \ldots, 4, i \in N\right)$ retained in the model explain 54.7 percent of the variance $\left(R^{2}=0,547\right)$.

Table 5. Regression coefficients

\begin{tabular}{|l|c|c|c|c|c|}
\hline & $\begin{array}{c}\text { Unstandardized } \\
\text { coefficients B }\end{array}$ & $\begin{array}{c}\text { Unstandardized } \\
\text { coefficients } \\
\text { Standard error }\end{array}$ & $\begin{array}{c}\text { Standardized } \\
\text { coefficients } \\
\text { Beta }\end{array}$ & $\boldsymbol{t}$ & Sig. \\
\hline Constant & 0,541 & 0,124 & & 4,354 & 0,000 \\
\hline & 0,185 & 0,058 & 0,179 & 3,190 & 0,002 \\
\hline & 0,171 & 0,053 & 0,159 & 3,226 & 0,001 \\
\hline & 0,169 & 0,059 & 0,167 & 2,845 & 0,005 \\
\hline & 0,351 & 0,054 & 0,343 & 6,506 & 0,000 \\
\hline
\end{tabular}

Source: designed by the authors

The result of the analysis is a linear regression specified by the equation (1) assigning weights of various variables according to their importance in definition of the relationship between the dependent $(Y)$ and independent $\left(X_{i}, i=1, \ldots, 4, i \in N\right)$ variables. 


$$
Y=0,541+0,185 X_{1}+0,171 X_{2}+0,169 X_{3}+0,351 X_{4}
$$

With a positive $\beta$ of 0.351 and correlation coefficient of 0,675 , the flexible response to changing business needs is the most influencing satisfaction of small and mediumsized enterprises with the policy of commercial banks concerning SMEs. Actually, it shows that small and medium-sized companies select the bank, which is able to take the most appropriate solution to solve their problem. The next factor that has an impact on satisfaction with the policy of banks concerning SMEs is granting of loans corresponding business needs $\beta$-value of 0,185 and a correlation coefficient of 0,672 . In fact, customers are satisfied when they can negotiate a loan that could help them to support or expand their current business or even start a new one. The third factor influencing satisfaction with the policy of banks concerning SMEs is offering appropriate financial services to business with a positive $\beta$ of 0,171 and correlation coefficient of 0,529 . It demonstrates that SME feel satisfactory when bankers are qualified and informed enough to arrange financials of their companies. The last element in the regression equation is creating favourable loan conditions with $\beta$-value of 0,169 and a correlation coefficient of 0,649 . This means that companies select a bank depending on ability of bank to create appropriate loan conditions, as it is very important for the business support and development.

\section{Conclusions}

Analysing the scientific literature regarding satisfaction of small and medium-sized enterprises with the policy of commercial banks concerning SMEs, it has been found that satisfaction is a very important element in relationship of bank and SME. Moreover, there are scientists claiming that satisfaction with the policy of commercial banks concerning SMEs is a vital element having impact on overall customers' satisfaction with financial institution.

Seven factors influencing small and medium-sized enterprises satisfaction with bank policy were investigated and the regression equation was established. It was found that all the variables in the regression equation are statistically significant. Moreover, it can be said that flexible reaction of bank to changing business needs is a factor having major impact on satisfaction of small and medium-sized enterprises with the policy of commercial banks concerning SMEs. In addition, it was also found that business support by a bank during a successful company's activities period, business support by a bank during a successful company's activities period in the critical moments of company's activities and making timely financing decisions are statistically insignificant elements that have almost no impact on satisfaction of small and medium-sized companies with the policy of commercial banks related to SMEs. In fact, the regression analysis showed that overall satisfaction of small and medium-sized enterprises with the policy of commercial banks concerning SMEs is a function of granting of loans corresponding business needs, offering appropriate financial services to business, creating favourable loan conditions and flexible response to changing business needs. 
To sum up, it becomes obvious that commercial banks should make efforts to improve all the variables that have an influence on satisfaction of small and medium-sized enterprises with the policy of commercial banks concerning SMEs, as bank policy is considered to be a very important determinant that has an impact on overall customers' satisfaction with the bank and on the financial results of the bank itself.

\section{References}

1. Adamoniene, R.; Trifonova, J. The State Support for Small and Medium-Sized Companies: General and Practical Aspects of Lithuania. The Economic Conditions of Enterprise Functioning. 2007, 51(1): 16-22 [interactive]. [accessed on 19-11-2013]. $<$ http://www.usapr.org/papers/paper.aspx?PaperID $=51>$.

2. Al-Eisa, A. S.; Alhemoud, A. M. Using a Multiple-Attribute Approach for Measuring Customer Satisfaction with Retail Banking Services in Kuwait. International Journal of Bank Marketing. 2009, 27(4): 294-314 [interactive]. [accessed on 19-11-2013]. $<$ http://www.emeraldinsight.com/journals.htm?articleid=1795876>.

3. Bennet, R. J. Expectations-Based Evaluation of SME Advice and Consultancy: An Example of Business Link Services. Journal of Small Business and Enterprise Development. 2007, 14(3): 435-457 [interactive]. [accessed on 19-11-2013]. <www. emeraldinsight.com/1462-6004.htm>.

4. Gill, A. S.; Flaschner, A. B.; Shachar, M. Factors that Affect the Trust of Business Clients in Their Banks. International Journal of Bank Marketing. 2006, 24(6): 348-405 [interactive]. [accessed on 17-06-2013]. <http://www.emeraldinsight.com/journals.ht $\mathrm{m}$ ?issn $=02652323 \&$ volume $=24 \&$ issue $=6 \&$ articleid $=1572850 \&$ show $=$ abstract $>$.

5. Jones, C. R. Customer Satisfaction Assessment for "Internal" Suppliers. Managing Service Quality. 1996, 6(1), 1: 45-48 [interactive]. [accessed on 19-11-2013]. <http:// www.emeraldinsight.com/journals.htm?articleid $=842472>$.

6. Kantsperger, R.; Kunz, W. H. Consumer Trust in Service Companies: A Multiple Mediating Analysis. Managing Service Quality. 2010, 20(1): 4-25 [interactive]. [accessed on 19-11-2013]. <www.emeraldinsight.com/0960-4529.htm>.

7. Kaura, V. Antecedents of Customer Satisfaction: A Study of Indian Public and Private Sector Banks. International Journal of Bank Marketing. 2013, 31(3): 167-186 [interactive]. [accessed on 11-11-2013]. <www.emeraldinsight.com/0265-2323.htm>.

8. Ravichandran, K.; Tamil Mani, B.; Arun Kumar, S.; Prabhakaran, S. Influence of Service Quality on Customer Satisfaction Application of Servqual Model. International Journal of Business and Management. 2010, 5(4): 117-124 [interactive]. [accessed on 19-11-2013]. <http://www.ccsenet.org/journal/index.php/ijbm/article/view/5158>.

9. Lundahl, N.; Vegholm, F.; Silver, L. Technical and Functional Determinants of Customer Satisfaction in the Bank-SME Relationship. Managing Service Quality. 2009, 19(5): 581-594 [interactive]. [accessed on 10-11-2013]. <www.emeraldinsight.com/ 0960-4529.htm>.

10. Mačerinskienè, I.; Railiene, G.; Rajangu, V. Evaluation of Business Finance Accessibility by Demand-Side Indicators. Conference Proceedings: 5th International Scientific 
Conference "Business and Management '2008". Vilnius, Lithuania, 2008, p. 235-241 [interactive]. [accessed on 16-11-2013]. <http://leidykla.vgtu.lt/conferences/BUS_ AND_MANA_2008/fin-engeneering/235-241-G-Art-Macerinskiene_Railiene_ Rajangu.pdf $>$.

11. Mačerinskiene, I.; Skvarciany, V. The Evaluation of Business Enterprises' Trust in Banks. KSI Transactions on Knowledge Society: A Publication of the Knowledge Society Institute. V International Science Conference "Knowledge Society". VI International Science Conference for Young Researchers "Technical Science and Industrial Management". 2012, 5(3): 5-11. Sofia: Knowledge Society Institute.

12. Madill, J. J.; Feeney, L.; Riding, A.; Haines Jr, G. H. Determinants of SME Owners' Satisfaction with Their Banking Relationships: A Canadian Study. International Journal of Bank Marketing. 2002, 20(2): 86-98 [interactive]. [accessed on 10-11-2013]. $<$ http://www.emeraldinsight.com/0265-2323.htm >.

13. Narteh, B. SME Bank Selection and Patronage Behaviour in the Ghanaian Banking Industry. Management Research Review. 2013, 36(11): 1061-1080 [interactive]. [accessed on 10-11-2013]. <www.emeraldinsight.com/2040-8269.htm>.

14. Statistics Lithuania. 2013 [interactive]. [accessed on 30-09-2013]. <http://db1.stat. gov.lt/statbank/selectvarval/saveselections.asp?MainTable $=$ M4010243\&PLanguage $=0 \&$ TableStyle $=\&$ Buttons $=\&$ PXSId $=13369 \& \mathrm{IQY}=\& \mathrm{TC}=\& S \mathrm{~T}=\mathrm{ST} \& \mathrm{rvar} 0=\& \operatorname{rvar} 1=$ \&rvar2=\&rvar3=\&rvar4 $=\& \mathrm{rvar} 5=\& \mathrm{rvar} 6=\& \mathrm{rvar} 7=\& \mathrm{rvar} 8=\& \mathrm{rvar} 9=\& \mathrm{rvar} 10=\& \mathrm{rv}$ $\operatorname{ar} 11=\& \operatorname{rvar} 12=\& \operatorname{rvar} 13=\& \operatorname{rvar} 14>$.

15. Vegholm, F. Relationship Marketing and the Management of Corporate Image in the Bank-SME Relationship. Management Research Review. 2011, 34(3): 325-336 [interactive]. [accessed on 17-11-2013]. <www.emeraldinsight.com/2040-8269.htm>.

16. Vegholm, F.; Silver, L. The Impact of Corporate Fairness on the Bank-SME Relationship. Journal of Financial Regulation and Compliance. 2008, 16(4): 352-364 [interactive]. [accessed on 19-11-2013]. <www.emeraldinsight.com/1358-1988.htm>.

17. Yap, B. W.; Ramayah, T.; Shahidan, W. N. W. Satisfaction and Trust on Customer Loyalty: A PLS Approach. Business Strategy Series. 2012, 13(4): 154-167 [interactive]. [accessed on 19-11-2013]. <http://www.emeraldinsight.com.skaitykla.mruni. eu/journals.htm?issn=1751-5637>.

18. Zhu, Y.; Chen, H. Service Fairness and Customer Satisfaction in Internet Banking. Exploring the Mediating Effects of Trust and Customer Value. Internet Research. 2012, 22(4): 482-498 [interactive]. [accessed on 10-11-2013]. <www.emeraldinsight.com/1066-2243.htm>.

19. Zineldin, M. Bank-Corporate Client "Partnership" Relationship: Benefits and Life Cycle. International Journal of Bank Marketing. 1996, 14(3): 14-22 [interactive]. [accessed on 10-11-2013]. <http://www.emeraldinsight.com/0265-2323.htm>.

20. Žvirelienè, R.; Bičiūnienè, I. Santykių marketingo dimensijų vaidmuo išlaikant vartotojus. Verslas: teorija ir praktika. 2008, 9(4): 272-280 [interactive]. [accessed on 19-11-2013]. <http://www.btp.vgtu.lt/index.php/btp/issue/archive>. 


\section{SMULKIOJO IR VIDUTINIO VERSLO İMONIŲ PASITENKINIMAS BANKŲ VYKDOMA POLITIKA}

Santrauka. Smulkiojo ir vidutinio verslo imonių pasitenkinimas komerciniais bankais yra vienas iš svarbiausių veiksnių, darančių ịtaką sèkmingai komercinių bankų veiklai. Straipsnyje ana-

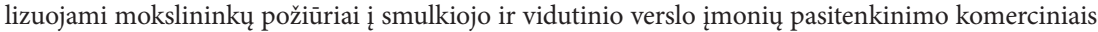
bankais svarbą. Analizuojant mokslines publikacija nustatyta, kad vienas iš svarbiausių veiksnių, darančių ịtaką smulkiojo ir vidutinio verslo i̇monių pasitenkinimui banku, yra komercinių bankų vykdoma politika smulkiojo ir vidutinio verslo įmonių atžvilgiu. Straipsnyje yra lyginami smulkiojo ir vidutinio verslo įmonių pasitenkinimo komercinių bankų vykdoma politika SVV įmonių atžvilgiu dviejų tyrimų rezultatai. Vienas tyrimas buvo atliktas Kanadoje 2002 m., kitas - Lietuvoje $2011 \mathrm{~m}$. Šiuose tyrimuose išskiriami ir nagrinèjami veiksniai, darantys ịtaką SVV įmonių pasitenkinimui komercinių bankų vykdoma politika jų verslo atžvilgiu, t. y.: kreditų, atitinkančių verslo poreikius, teikimas; kitų reikiamų finansinių paslaugų verslui teikimas; palankių paskolų sąlygų sudarymas; lankstus reagavimas ị kintančius verslo poreikius; verslo rèmimas sẻkmingu įmonės veiklos laikotarpiu; verslo rèmimas kritiniais įmonès veiklos momentais; finansinių sprendimų priėmimas laiku. Nustatyta, kad visi ryšiai yra tiesiniai ir koreliacijos koeficientai gana aukšti, kas parodo, kad ryšiai tarp veiksnių yra pakankamai stiprūs. Tačiau šiuose tyrimuose nebuvo nustatyta, ar visi elementai yra statistiškai reikšmingi ir ar jie tikrai turi ịtakos pasitenkinimui komercinių bankų vykdoma politika. İ dabartinị tyrimą įtraukti visi veiksniai, kurie buvo tirti ankstesniuose tyrimuose. Tyrimui atlikti taikytas anketinès apklausos metodas. Respondentai buvo Lietuvos smulkiojo ir vidutinio verslo įmonių darbuotojai. Atlikus statistinį tyrimą, buvo nustatyta, kad tik kreditų, atitinkančių verslo poreikius, teikimas; reikiamų finansinių paslaugų verslui teikimas; palankių paskolų sąlygų sudarymas; lankstus reagavimas i kintančius verslo poreikius yra statistiškai reikšmingi elementai SVV pasitenkinimui komercinių bankų vykdoma politika. Be to, buvo nustatyta, kad tarp šių veiksnių nèra multikolinearumo, nèra išskirčių, todèl, buvo sudaryta smulkiojo ir vidutinio verslo įmonių pasitenkinimo komercinių banko vykdoma politika SVV įmonių atžvilgiu regresine lygtis, kuri parodo, kokị svorị kiekvienas iš statistiškai reikšmingų elementų turi pasitenkinimui komercinio banko vykdoma politika. Kitaip tariant, lygtis parodo, kaip pasikeičia pasitenkinimas komercinių bankų vykdoma politika pasikeitus lemiančiam veiksniui, kas leidžia prognozuoti pasitenkinimo kitimą.

Daiva JUREVIČIENĖ, Doctor of Social Sciences, Mykolas Romeris University, Faculty of Economics and Finance Management, Department of Banking and Investments, Professor. Research interests: personal finances, individual financial behaviour, investments, banking, risk management.

Daiva JUREVIČIENĖ - Mykolo Romerio universiteto Ekonomikos ir finansų valdymo fakulteto Bankininkystės ir investicijų katedros profesorè, socialinių mokslų daktarè. Mokslinių tyrimų sritys: asmeniniai finansai, individų finansinè elgsena, investicijos, bankininkysté, rizikos valdymas.

Viktorija SKVARCIANY, Mykolas Romeris University, Faculty of Economics and Finance Management, Department of Banking and Investments, lecturer, PhD student. Research interests: banking, trust and satisfaction with financial institutions.

Viktorija SKVARCIANY - Mykolo Romerio universiteto Ekonomikos ir finansų valdymo fakulteto Bankininkystès ir investicijų katedros ekonomikos krypties doktorantè ir lektorè. Mokslinių tyrimų sritys: bankininkystė, pasitenkinimas ir pasitikejimas finansinėmis institucijomis. 